\author{
Научная статья \\ УДК 376.4(571.56) \\ DOI: $10.18101 / 2307-3330-2021-2-81-86$
}

\title{
ПСИХОЛОГО-ПЕДАГОГИЧЕСКОЕ СОПРОВОЖДЕНИЕ ДЕТЕЙ С ОВЗ в УСЛОВИЯх ЮЖнОЙ ЯкУТИИ
}

\author{
(C) Шпиллер Татьяна Валерьевна \\ старший преподаватель, \\ Технический институт (филиал) Северо-Восточного федерального университета \\ имени М. К. Аммосова \\ Россия, 678960, г. Нерюнгри, ул. Кравченко, 16 \\ tanya1989pl@mail.ru
}

\begin{abstract}
Аннотация. В статье представлен опыт психолого-педагогического сопровождения детей с ограниченными возможностями здоровья (OB3) в условиях Южной Якутии. Описаны пути организации образовательного процесса для детей с OB3, рассматриваются условия психолого-педагогического сопровождения с участием педагогов, родителей и учащихся, направленные на оптимизацию психического и физического развития ребенка, эмоционального и социального благополучия. Анализ работы педагогов показывает, что взаимодействие с детьми с ОВ3 это комплексная технология поддержки и помощи ребенку, родителям в решении задач развития, обучения, воспитания и социализации. Авторами рассматриваются технология проблемного обучения, технология разноуровневого обучения, технология экологического путешествия. Технология СА-ФИ-ДАНСЕ - это танцевально-ритмическая гимнастика, игрогимнастика, креативная гимнастика, пальцевая гимнастика, игровой самомассаж и т. д.

Ключевые слова: психолого-педагогическое сопровождение, дети с ограниченными возможностями здоровья, развитие личности, социализация, дети-инвалиды, проблемное обучение, разноуровневое обучение, здоровьесбережение.
\end{abstract}

\section{Для цитирования}

Шпиллер Т. В. Психолого-педагогическое сопровождение детей с ОВ3 в условиях Южной Якутии // Вестник Бурятского государственного университета. Образование. Личность. Общество. 2021. № 2. С. 81-86.

Обучение и воспитание детей-инвалидов и детей с ограниченными возможностями здоровья (OB3) являются одним из основных и неотъемлемых условий их успешной социализации, обеспечения их полноценного участия в жизни общества, эффективной самореализации в различных видах профессиональной и социальной деятельности. С учетом того, что в последние годы количество детей с ОВ3 увеличивается, перед специалистами различных учреждений встает вопрос о поиске новых форм психолого-педагогической работы с такими детьми.

В Нерюнгринском районе Республики Саха (Якутия) во всех учреждениях, где обучаются и воспитываются дети с ОВ3, занимаются квалифицированные специалисты: дефектологи, логопеды, психологи. Ими используются специальные оборудования и современные технические средства обучения для проведения коррекционных занятий, а также специальные развивающие программы. Анализ работы педагогов показывает, что взаимодействие с детьми с ОВ3 - это 
комплексная работа поддержки и помощи ребенку, родителям в решении задач развития, обучения, воспитания и социализации. На эффективность занятий с детьми с ОВЗ влияют грамотно подобранные формы и методы работы. Рассмотрим некоторые из них.

Так, например, Е. С. Аксенова, учитель начальных классов МБОУ «С(К) НШ-ДС № 2» г. Нерюнгри в своей работе использует технологию проблемного обучения, направленную на всестороннее развитие личности учащегося. Она специально создает проблемную ситуацию путем применения особых методических приемов. Так во время беседы она ставит перед детьми проблемные задачи и последовательные взаимосвязанные вопросы, ответы на которые приведут учащихся к решению задачи [1, с. 22]. Также применяет технологию разноуровнего (дифференцированного) обучения, который чаще всего проводит на контрольно-обобщающих уроках. Например, при выполнении самостоятельной работы детям «послабее» разрешает пользоваться опорами, увеличивает время выполнения заданий. Использует здоровьесберегающие технологии: правильно организованное обучение детей с ОВЗ и использование в ходе занятий здоровьесберегающих технологий способствуют укреплению их психического и физического здоровья. Например, педагог использует такие упражнения, как на развитие ориентации в пространстве и собственном теле, дыхательную гимнастику, зрительную гимнастику, также в своей работе использует различные информационные технологии, которые способствуют разнообразию используемого на занятиях дидактического и демонстрационного материала (тесты, тренажеры, логические задания).

В МДОУ № 60 «Огонек», г. Нерюнгри работают четыре группы компенсирующей направленности для детей с задержкой психического развития, и одна группа для детей с интеллектуальной недостаточностью. На базе учреждения создан креативпарк «От игры к Успеху». Целью коррекционно-педагогической работы с дошкольниками, отстающими в развитии, является формирование психологического базиса для полноценного развития личности каждого ребенка, «предпосылок» формирования познавательных процессов, развитие зрительных, слуховых, моторных функций и межсенсорных связей, пробуждение познавательной и творческой активности ребенка.

Креатив-парк «От игр к успеху» работает по следующим направлениям:

1) лаборатория «ВебАртТуризм» направлена на создание интеллектуальномотивационной среды, на поддержку и развитие интереса воспитанников;

2) лаборатория «Технобум», в которой осуществляется проектирование и разработка воспитанниками различных лего и робототехнических устройств и приборов (Конструкторы Lego, Робототехника Lego WEDO 2.0 и HUNA (OCT) Мое время для робототехники «Brain A») [2, с. 18];

3) «лаборатория игры» направлена на возможность «примерять» на себя роль представителей различных специальностей, используя разнообразие игр (сюжетно-ролевые, театральные игры, игры с песком, изобразительная деятельность и др.) [5, с. 12];

4) «школа Успеха» направлена на формирование информационнокоммуникативных компетенций воспитанников, создание и реализацию медийной продукции, выполнение индивидуальных проектов «Живые истории». 
Вся работа креатив-парка направлена на развитие творческих способностей, расширение кругозора и познавательной активности детей. Педагоги стараются обеспечить реализацию интересов, способностей, склонностей детей к разным видам деятельности; сформировать позитивные установки к различным видам труда и творчества.

М. В. Жижа, воспитатель МДОУ № 46 «Незабудка» г. Нерюнгри, предлагает модель сопровождения детей с ОВ3 в образовательном пространстве «Птичий терренкур» (в рамках проекта ДОУ «Образовательный туризм»).

Экологическому воспитанию и образованию воспитанников групп компенсирующей направленности для детей с ЗПР в муниципальном дошкольном образовательном учреждении № 46 «Незабудка» поселка Серебряный Бор Нерюнгринского района всегда уделялось большое внимание. На современном этапе педагогический коллектив апробирует новую инновационную модель сопровождения детей с ОВ3 в образовательном пространстве учреждения по экологическому воспитанию и образованию в формате деятельности туристического агентства «Эко-travel». Турагентство «работает» с октября 2018 г. и является одним из основных направлений педагогического инновационного проекта. Работа туристического агентства «Эко-travel» построена по технологии «образовательного экологического путешествия», основной задачей которого является создание условий от простого передвижения в пространстве ДОУ в поисках новых впечатлений. Вся образовательная деятельность в рамках туристического агентства «Эко-travel» ориентирована на развитие личности ребенка, в том числе и ребенка с ОВ3, на его умение выстроить диалог с окружающими миром.

Пилотным проектом турагентства стала работа по созданию естественнообразовательного терренкура [3]. Был разработан алгоритм создания «Станции». Каждая «Станция» - это место размещения на территории ДОУ «семейки» определенной птицы: сороки, снегиря, дятла, синицы, сойки, воробья, кукушки. Обязательным условием открытия экоплощадки является серия тематических занятий (в количестве 8) для воспитанников, фигурки птицы, вывеска, кормушка, папка «Справочное бюро», чемоданчик для путешествий, места для игр и отдыха. Материал, который используется для оформления станции, в основном природный: ветки, доски, рейки, фанера, а также бросовый материал, которому дается «вторая жизнь»: фломастеры, пластиковые ложечки от детского питания, веревки, различные пластиковые емкости, остатки пластиковых панелей, пластиковые и металлические чемоданчики и т. д. Место размещения каждой птицы определялось по принципу: доступности для подхода, рассматривания, взаимодействия и беспрепятственного наблюдения в зимний период из окон группы. Все станции размещаются на деревьях по периметру здания детского сада или на прогулочном участке данной группы. Пилотной станцией стала остановка «Сорока», она приняла первых «путешественников» в мае 2019 г.

Открытие «станций» идет по определенному графику, с учетом выбранной птицы, природного календаря и климатических условий. Например, станция «Кукушка» была открыта в начале сентября 2019 г. Кукушка - это единственная перелетная птица в группе выбранных птиц. Устроители «станции» торопились обустроить остановку и познакомить воспитанников ДОУ до наступления морозов с особенностями этой птицы. 
На сегодняшний день идея создания «Птичьего терренкура» практически воплощена в жизнь. Открытие каждой новой «станции» - это событие для всех воспитанников детского сада. С появлением новой «станции» на маршруте «Птичий терренкур» туристическому агентству «Эко-travel» приходится прокладывать новые маршруты для каждой группы индивидуально, в зависимости от цели путешествия, возраста воспитанников. Таким образом, на территории детского сада усилием всех участников создаются комфортные, эстетичные экоплощадки для оздоровления воспитанников и систематического общения с живой природой.

М. А. Прима, инструктор по физической культуре МБОУ «С (К)НШ-ДС № 2» г. Нерюнгри, проводит физкультурно-оздоровительную работу с детьми ОВЗ посредством технологии СА-ФИ-ДАНСЕ. Данное учреждение посещают дети с НОДА и ЗПР, у которых нарушена осанка, координация движений, нет выносливости, чувствуется нехватка здорового соперничества в подвижных игpax, дошкольники не испытывают радость от своих побед и побед своих товарищей.

Результаты начального обследования уровня физического развития воспитанников показали, что основные движения детей развиты недостаточно, высокий уровень имеют $38 \%$ детей, средний $-20 \%$, низкий- $42 \%$. Для решения этой проблемы разработана система использования технологии Ж. Е. Фирилевой САФИ-ДАНСЕ на занятиях по физической культуре, которая основана на повышении интереса к физической культуре за счет введения увлекательных форм работы во всех частях занятий. Задания на создание радостного настроения, самовыражение и раскрепощение мотивируют детей на активную двигательную деятельность и содействуют их всестороннему развитию. Технология СА-ФИДАНСЕ включает в себя разнообразные формы работы на занятиях по физической культуре, такие как:

1) танцевально-ритмическая гимнастика - различные виды ходьбы, танцевальные шаги, подскоки и бег под музыку [4, с. 24];

2) игрогимнастика - разнообразные движения, в результате которых у детей развиваются координация, гибкость, осанка, формируется правильное дыхание;

3) креативная гимнастика на разных этапах занятия - формирует правильное дыхание, дает детям возможность выплеснуть свою энергию, помогает достичь психофизического равновесия и развить творческие возможности;

4) игровой самомассаж - в зависимости от целей занятия на разных этапах способствует развитию навыков собственного оздоровления, а также поднятию настроения, снятию психического напряжения и стресса, является закаливающей процедурой;

5) пальчиковая гимнастика - задания на развитие ручной умелости.

Применение технологии СА-ФИ-ДАНСЕ способствует улучшению уровня физической подготовленности дошкольников, активизации интереса воспитанников к спортивным занятиям и утренней гимнастике.

Таким образом, организация психолого-педагогического сопровождения развития ребенка с ОВ3 в образовательных учреждениях является комплексной с учетом применения различных технологий. Рассмотренные технологии являются 
эффективными и оказывают положительное влияние на процесс обучения и воспитания детей с ограниченными возможностями здоровья в условиях современного образования.

\title{
Литература
}

1. Ягодко Л. И. Использование технологии проблемного обучения в начальной школе // Начальная школа плюс До и После. 2010. № 1. С. 36-38. Текст: непосредственный.

2. Волосовец Т. В., Маркова В. А., Аверин С. А. SТЕМ-образование детей дошкольного и младшего школьного возраста. Парциальная модульная программа развития интеллектуальных способностей в процессе познавательной деятельности и вовлечения в научно-техническое творчество: учебная программа. Москва: БИНОМ. Лаборатория знаний, 2018. С. 18. Текст: непосредственный.

3. Чепракова Н. В. Терренкур - маршрут оздоровления. Из опыта работы. Инновационные формы оздоровления детей дошкольного возраста // Актуальные вопросы современной педагогики: материалы IV Международной научной конференции (г. Уфа, ноябрь 2013 г.). Уфа: Лето, 2013. С. 67-70. Текст: непосредственный.

4. Фирилева Ж. Е., Сайкина Е. Г. СА-ФИ-ДАНСЕ. Танцевально-игровая гимнастика для детей: учебное пособие для педагогов дошкольных и школьных учреждений. Санкт-Петербург: Детство-Пресс, 2007. 323 с. Текст: непосредственный.

5. Балбекова О. Б. Наглядно-дидактический комплект «Моделирование игрового опыта детей». Москва, 2020. 64 с. Текст: непосредственный.

Статья поступила в редакиию 05.06.2021; одобрена после рецензирования 05.07.2021; принята к публикациии 29.11.2021.

\section{PSYCHOLOGICAL AND PEDAGOGICAL SUPPORT FOR CHILDREN WITH DISABILITIES IN THE CONDITIONS OF SOUTH YAKUTIA}

\author{
Tatyana V. Shpiller \\ Senior Lecturer, \\ Technical Institute (branch) of Ammosov North-Eastern Federal University \\ 16 Kravchenko St., Nerungri 678960, Russia \\ tanya1989pl@mail.ru
}

\begin{abstract}
The article presents the experience of psychological and pedagogical support for children with disabilities in the conditions of South Yakutia. We have described the ways of organizing the educational process for special children, the psychological and pedagogical assistance with the participation of teachers, parents and pupils aimed at optimizing the mental and physical development of children with disabilities, their emotional and social welfare. The analysis of teachers' experience shows that interaction with children with disabilities is a complex technology of support and assistance to the child, his parents in solving problems of development, education, and socialization. We have considered such technologies as the technology of problem-based learning, the technology of multi-level learning, the technology of ecological travel. SA-FI-DANCE technology is dance-rhythmic gymnastics, play-based gymnastics, creative gymnastics, finger gymnastics, play-based self-massage, etc.
\end{abstract}


Keywords: psychological and pedagogical support, children with disabilities, personal development, socialization, disabled children, problem-based learning, multi-level education, health protection.

\section{For citation}

Shpiller T. V. Psychological and Pedagogical Support for Children with Disabilities in the Conditions of South Yakutia. Education. Person. Society. 2021; 2: 81-86 (In Russ.).

The article was submitted 05.06.2021; approved after reviewing 05.07.2021; accepted for publication 29.11.2021. 